\title{
Comparing the Power and Influence of Functional Managers With that of Project Managers in Matrix Organisations: The Challenge in Duality OF COMMAND
}

\author{
Dylon Moodley, Margie Sutherland and Pieter Pretorius \\ Gordon Institute of Business Science, University of Pretoria \\ Accepted: October 2015
}

\begin{abstract}
Since its inception four decades ago, there has been widespread adoption of the matrix organisational design, particularly in project-based organisations. However, several challenges remain, one of which is related to the ambiguity of authority as a result of the dual command structure. This study examines the perceptions of the types of power and influence mechanisms used by the functional manager and the project manager to influence project personnel, and the effect of these mechanisms on attitudinal outcomes. The research used a two-phase design. The first qualitative phase validated the constructs of power and influence. In Phase 2, quantitative data was obtained from 22 functional managers, 28 project managers and 92 project personnel in South Africa, Italy and Canada from one large project execution technology company. There appears to be a large perceptual gap between project managers, functional managers and project personnel. Managers perceive themselves to be using aspirational and personal influence mechanisms, whereas project personnel perceive the managers to be using positional, punitive mechanisms. Relationships were observed between the perceived type of influence being used by the managers and the project personnel's satisfaction with their manager, overall job satisfaction, their performance and level of engagement. Functional and project managers are associated with very different attitudinal outcomes among project team members.
\end{abstract}

Key words: power, matrix organisations, project managers, functional managers

JEL: L2

\section{Introduction}

Increasingly, markets are becoming more complex, and, in response, companies are adopting more complex forms of organisational design (Sy \& Côté, 2004). In response to strategies that require increased collaboration across customer, geographic, function, and product dimensions, many companies use a matrix structure to formally connect the disparate elements of their organisations (Kates \& Galbraith, 2007). Academic literature has focused primarily on the matrix structural design and process issues. However, many of the known challenges in the matrix organisation relate to ambiguity of authority with regard to the dual command structure (Goold \& Campbell, 2003; Sy \& D’Annunzio, 2005). Kates and Galbraith (2007:110) define a matrix as an organisation in which "some employees have two or more bosses". In matrix organisations, formal authority to direct project personnel lies with functional managers, whilst the responsibility for coordinating and executing work efforts lies with project managers (Dunne, Stahl \& Melhart, 1978; Goold \& Campbell, 2003). This ambiguity in terms of authority that results from this organisational design (Sy \& Côté, 2004) requires a deeper understanding of how these two types of managers influence project team members to respond to the execution of project responsibilities.

The structuring of organisations into project teams in order to achieve organisational objectives has become ubiquitous in all sectors of the economy in recent decades (Packendorff \& Lindgren, 2014). The latter authors go on to say that most traditional firms have transformed into projectbased firms where almost all operations are organised as projects, and where permanent structures fulfil the function of administrative support. This dovetails with the matrix organisation discussed 
above. Packendorff and Lindgren (2014) enquire as to what type of power structures emerge in this "projectification" of organisations.

According to Sy and Côté (2004), there have been few studies that have examined the interpersonal skills required for effective operation in a matrix organisation. The effective acquisition and use of power and influence are necessary for managing relationships and success in organisations (Benfari, Wilkinson \& Orth, 1986). Yukl and Falbe (1990:132) point out that "one of the most important determinants of managerial effectiveness is success in influencing subordinates, peers, and superiors". Bartlett and Ghoshal (1990) propose that designing a superior structure on its own does not ensure success; successful management is required within a structure. In spite of the importance of this, little recent empirical research has been conducted on the influence behaviour of managers (Yukl \& Falbe, 1990), particularly in matrix structures.

A seminal study was conducted on this topic 35 years ago in a military environment (Dunne et al., 1978). Given that most aspects of how organisations are managed have changed in the interim, particularly with the advent of information technology, this study will in part replicate that study to test its current validity. The purpose of this study is to examine perceptions of the sources of power and influence used by the two types of managers in a project matrix organisation and in ensuing influence in respect of project personnel work attitudes.

\section{Theoretical framework of the matrix organisation}

\subsection{The nature of the matrix organisation}

Kates and Galbraith (2007) state that the matrix organisational design has the ability to deliver solutions across geographic boundaries and provide multiple product offerings with increased internal collaboration. This has led to the prolific adoption of the matrix organisation across most industries internationally. The matrix organisational structure is a grid-like structure with horizontal and vertical dimensions representing functions, geographical zones, projects or products, as indicated in Figure 1 (Authors' own interpretation of the matrix structure). This structure allows multiple business dimensions to be executed simultaneously (Sy \& Côté, 2004; Sy \& D'Annunzio, 2005). There is extensive coverage in academic literature of the reasons why matrix organisations are adopted and of the practical challenges that are prevalent in them (Davis \& Lawrence, 1978; Galbraith, 1971; Kates \& Galbraith, 2007; Larson \& Gobeli, 1987; Sy \& Côté, 2004). Examination of the challenges shows that these are largely related to interpersonal issues. Academic research has primarily focused on addressing the structural issues, not the interpersonal issues (Sy \& Côté, 2004) in which these challenges are rooted.

Figure 1

Typical matrix organisation structure

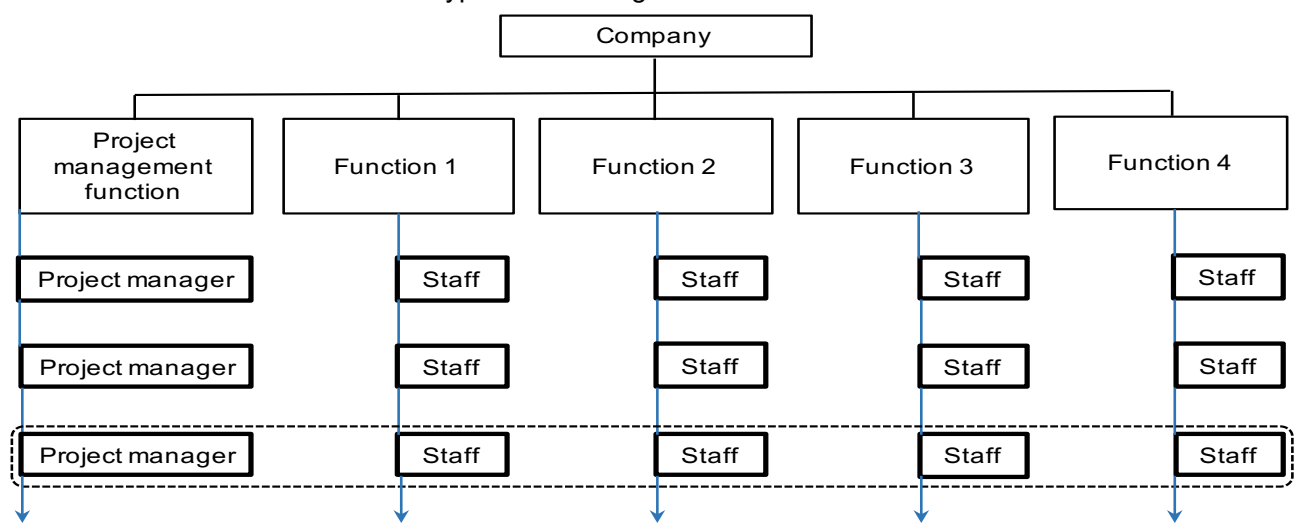

Source: Author's own interpretation 


\subsection{The dillemma and unavoidable challenges of the matrix organisation}

At the intersection of the vertical and lateral structures are people who belong to more than one grouping. For a person at this intersection (referred to as "project personnel"), this implies that they have a technical responsibility towards the project and project manager, but that their performance and promotion are assessed and determined by the functional manager. The dilemma of authority versus responsibility is thus evident in a matrix structure. The functioning together of the what (functional) and the how (project) requires shared responsibility for, and authority over, the operational flow of work (Larson \& Gobeli, 1987).

The ambiguity in terms of authority resulting from this dual command structure (Sy \& Côté, 2004) requires a deeper understanding of how these two types of managers influence project team members to respond to the execution of project responsibilities, which, incidentally, violates a major principle of management: "single, scalar chain of command" (Nicholas \& Steyn, 2008). The distribution of power is determined by the interaction of behaviour and structure (Brass \& Burkhardt, 1993). The literature indicates that an important issue in the matrix organisation is the concern with misaligned goals and objectives primarily related to different types of managers having different objectives (Sy \& D’Annunzio, 2005). This misalignment typically results in conflict and confusion about loyalty or commitment to the two different managers (Nicholas \& Steyn, 2008).

The attributes of power (related to the various bases of power), legitimacy (related to authority) and urgency (related to task execution) play a pivotal role in understanding and defining stakeholder relationships (Mitchell, Agle \& Wood, 1997). The focus of this study is the examination of power use and distribution in the triangular arrangement (Davis \& Lawrence, 1978) of three stakeholder groups as depicted in Figure 2. In this dual reporting structure, the relationship between the project manager and project personnel (Dunne et al., 1978) is often expressed as a dotted-line relationship, with the project personnel reporting temporarily to a project manager for the purposes of executing a specific project. The relationship between functional manager and project personnel (Dunne et al., 1978) is a formal reporting relationship depicted as a solid line where functional managers are usually responsible for the expertise, reward, compensation, performance appraisal and development aspects pertaining to their staff. The dual reporting structure in a matrix presents unavoidable challenges of conflict and confusion experienced by project personnel when responsibility and authority overlap in vertical and lateral structures (Davis \& Lawrence, 1978).

Figure 2

Stakeholder relationships in a matrix organisation

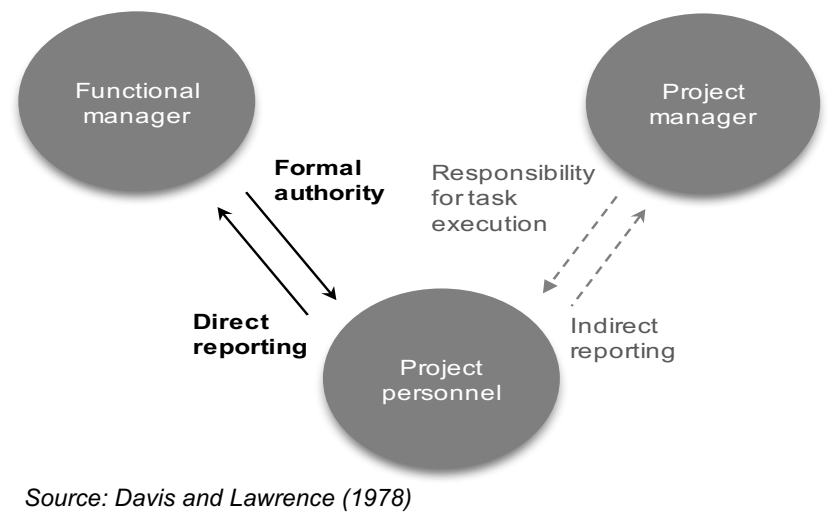

Nicholas and Steyn (2008) further describe the conflicts experienced by the managers themselves. Functional managers fear that their authority will be undermined and that they (the managers) will simply be performing support functions, that is, providing resources for the projects that require them, especially when project funding runs through a project function. Project managers also have 
fears, since they have very little or no control over the resources having to do the work, and how to incentivise them. These fears will obviously influence the way managers behave, and how they will employ their power to achieve what they have set out to achieve.

\subsection{Power relationships within matrix organisations}

The processes of power are both pervasive and complex. Power is generally defined in terms of a relationship, whereby an agent influences, or attempts to influence, a target with the intended outcome being some form of action or behavioural change (Benfari et al., 1986; French \& Raven, 1959; Yuk1, Kim \& Falbe, 1996). French and Raven (1959), in their seminal work, found that power and influence exist in a dyadic relationship between agent and target. Researchers are divided as to whether power and influence are distinct constructs (Yukl et al., 1996) or exist together in structures (Willer, Lovaglia \& Markovsky, 1997). The focus of this study will not be on the distinction between power and influence but rather on the areas of overlap between the power bases (French \& Raven, 1959) and influence tactics (Kipnis, Schmidt \& Wilkinson, 1980; Greiner \& Schein, 1988).

Yukl et al. (1996) explore power as the potential influence derived from the attributes of the influencer, the relationship between influencer and influenced, and the influencer's position in the organisation. In the context of hierarchical relationships within an organisation, legitimate or authoritarian power resides in the position within the organisational structure (Benfari et al., 1986; French \& Raven, 1959). However, "the potential power of the individual manager is embedded in the networks of social interactions that are part of the work setting" (Benfari et al., 1986:12). Influence is described as kinetic power, and, to be effective, it is rooted in a base of power (Willer et al., 1997).

There is a wide range of power bases and influence tactics available to managers. French and Raven's (1959) seminal work has been built on for half a century (e.g. Benfari et al.,1986; Yukl \& Falbe,1990; Koslowsky, Schwarzwald \& Ashure 2001; Yukl, Seifert \& Chavez, 2008; Gupta \& Sharma, 2008; Greiner \& Schein, 1988; Raven, 2008). Raven (2008) proposed a power interaction model whereby an influencing agent chooses a specific power base for gaining compliance. Gupta and Sharma (2008) studied compliance with bases of power and found that employees attribute more of their compliance to the use of soft bases of power rather than harsh bases of power. Soft bases of power are related to the use of personal rather than organisational resources to gain compliance, whilst harsh bases of power are related to a superior position in the organisation. This discussion on the link between power and influence is necessary, as the survey instrument was based on 12 types of influence tactics and power bases developed from the literature (Dunne et al., 1978; French \& Raven, 1959; Benfari et al.,1986; Yukl \& Falbe, 1990; Yukl et al., 2008; Gupta \& Sharma, 2008; Raven, 2008) and Phase 1 of the study shown in Table 1.

Table 1

Power bases and influence tactics used in the study

\begin{tabular}{|l|l|l|}
\hline \multicolumn{1}{|c|}{$\begin{array}{c}\text { Power and } \\
\text { influence } \\
\text { constructs }\end{array}$} & \multicolumn{1}{|c|}{ Explanation } & Power base \\
\hline Association & $\begin{array}{l}\text { "Association" refers to referent power and the desire by individuals to be linked with a } \\
\text { manager in the organisation. }\end{array}$ & Hard \\
\hline Authority & $\begin{array}{l}\text { "Authority" refers to formal authority derived from a position in the organisational } \\
\text { structure. It is typically linked to coercion. }\end{array}$ & Hard \\
\hline Empowerment & $\begin{array}{l}\text { "Empowerment" speaks to the idea of delegation of authority, creating a sense of } \\
\text { ownership, and equipping individuals with the correct skills and tools. }\end{array}$ & Soft \\
\hline Good relationship & $\begin{array}{l}\text { "Good relationship" refers to influencing based on friendship or a relationship in order to } \\
\text { achieve an outcome. This is also linked to referent power. }\end{array}$ & Soft \\
\hline $\begin{array}{l}\text { Passion and } \\
\text { inspiration }\end{array}$ & $\begin{array}{l}\text { This refers to influence based on inspiration and personal appeals and is also rooted in } \\
\text { referent power. This speaks to leadership ability as a means of influencing. }\end{array}$ & Soft \\
\hline Logical arguments & $\begin{array}{l}\text { "Logical arguments" refers to both informational and expert power and the use of } \\
\text { rational persuasion by managers. }\end{array}$ & Either \\
\hline
\end{tabular}




\begin{tabular}{|l|l|l|}
\hline \multicolumn{1}{|c|}{$\begin{array}{c}\text { Power and } \\
\text { influence } \\
\text { constructs }\end{array}$} & \multicolumn{1}{|c|}{ Explanation } & Power base \\
\hline Penalty pressure & $\begin{array}{l}\text { This refers to coercion as a power base and the use of pressure as an influence } \\
\text { mechanism to obtain a result or behaviour change. }\end{array}$ & Hard \\
\hline Performance rating & $\begin{array}{l}\text { This is rooted in both reward and coercive power and is executed as ingratiation, } \\
\text { exchange, apprising or pressure as an influence mechanism. It typically refers to the } \\
\text { company reward system. }\end{array}$ & Hard \\
\hline $\begin{array}{l}\text { Position \& } \\
\text { responsibilities }\end{array}$ & $\begin{array}{l}\text { This construct is included to create a difference between formal and informal authority. } \\
\text { Position and responsibility speak to legitimate power but are not authority and may arise } \\
\text { from either a direct or indirect relationship. }\end{array}$ & Hard \\
\hline $\begin{array}{l}\text { Professionally } \\
\text { challenging }\end{array}$ & $\begin{array}{l}\text { This construct speaks to the idea of creating meaning and value through work, and } \\
\text { even a sense of belonging in the organisation. This can be used as an influence } \\
\text { mechanism. }\end{array}$ & Either \\
\hline Respect knowledge & $\begin{array}{l}\text { This refers to expert power. Having respect and confidence in the manager's abilities } \\
\text { and advice, and therefore responding to a rational, persuasive influence mechanism } \\
\text { used by the manager. }\end{array}$ & Soft \\
\hline Shared goals & $\begin{array}{l}\text { This construct is related to working together to achieve common goals and speaks to } \\
\text { the idea of alignment between manager and project personnel. It is executed as an } \\
\text { influence mechanism through collaboration and consultation. }\end{array}$ & Soft \\
\hline Sources: Dunne et al., 1978; French \& Raven, 1959; Benfari et al., 1986; Yukl \& Falbe, 1990; Yukl et al., 2008; Gupta \& \\
Sharma, 2008; Raven, 2008
\end{tabular}

\subsection{Earlier study on the use of power in matrix organisations}

The original study by Dunne et al. (1978) found that perceptions of the use of power and influence by managers and project personnel are the same. The second finding was that project personnel's reasons for compliance with the dictates of functional and project managers are different, implying that these managers use different sources of power and influence as a means for achieving compliance. The study tested outcomes of the use of power and influence tactics on the attitudinal variables: perceived degree of support, willingness to disagree, work involvement and job satisfaction. The key finding of the study was that position responsibility, respecting knowledge and being professionally challenging were positively associated with those attitudes. No replication of this study since the original study was conducted in 1978, could be found in the literature. A replication of this study after nearly four decades can, therefore, contribute to an understanding of what has changed and what has remained the same, which confirms the relevance of this paper.

\subsection{Application of the framework for this study}

In this study, perceptions of how the power and influence tactics used by the two types of managers affect attitudinal variables, were examined. People base their behaviour on their perception of reality, not reality itself (Robbins \& Judge, 2013). This study examines the perceptions of power and influence from the perspective of the initiators of the use of power and influence, namely functional and project managers, and of the perceiver of the types of power and influence used, namely the project personnel. Joyce (1986) found that the effects of organisational processes in the matrix design affect employees' perceptions and work attitudes. In considering the effects of the matrix power relationship on attitudes, studies by Reeser (1969) and Rizzo, House and Lirtzman, (1970) have shown that the introduction of the dual reporting system can cause role conflict and ambiguity, with the resultant effect being the production of "negative effects on work attitudes like job satisfaction and involvement" (Joyce, 1986:536). It is also noted that quality of interaction has been demonstrated to play a moderating role between the bases of power and compliance, on the one hand, and subordinates' attitudes to superiors (Gupta \& Sharma, 2008).

Job satisfaction can be defined as the positive feeling resulting from the complex evaluation of several dimensions, including the actual work, interaction with various stakeholders, organisational politics, and rules and conditions of work (Robbins \& Judge, 2013). The summation of these individual elements provides the employee with a personal level of job satisfaction which is widely assumed to underpin performance levels of staff (Robbins \& Judge, 2013). Harter, 
Schmidt and Hayes (2002) carried out a meta-analysis of employee engagement and job satisfaction research and discovered the critical importance of the influence of the supervisor over both employee engagement and satisfaction with the company, and found that the construct most highly related to staff performance was satisfaction with the supervisor. Thamhain and Gemmill (1974) established that the perceived degree of support from the manager was negatively correlated with the manager's use of coercive power. Koslowsky et al. (2001) found that job satisfaction was positively related to compliance with the dictates of managers who used soft power sources and negatively associated with the use of harsh sources. However, they found that employee commitment was positively associated with the use of both harsh and soft power sources. Employee engagement is considered to be an employee's involvement with, enthusiasm for, and satisfaction with the work the employee does (Robbins \& Judge, 2013). This expression of employee engagement as a work attitude is critical, as research has shown a correlation between employee engagement and meaningful business outcomes (Harter et al., 2002). Rousseau (2004) introduced and developed the concept of psychological contracts to express the complex set of expectations that employer and employee have of each other. The degree to which these are fulfilled has been shown to have wide-ranging effects on job satisfaction, motivation, commitment, and intention to quit (Wocke \& Sutherland, 2008). Appelbaum, Nadeau and Cyr (2009) and Sy and D'Annunzio (2005) indicate that very little work has been done to understand staff performance in a matrix organisation. Appelbaum et al. (2009) pose the key question: "What are the functional and project managers' roles in the performance process?" The functional manager is responsible for managing the overall performance of the employee, but the project manager has greater day-to-day interaction with the entire project team.

\section{Research objectives}

The literature above shows that, despite the prolific adoption of matrix organisations in projectbased organisations, there are significant challenges inherent in it; in particular that the dual command structure produces ambiguity of authority. Power and influence are exercised in a variety of ways by managers. With the paucity of recent research in this field, there is a need to understand how the power and influence tactics used by the two types of managers are viewed, and what the attitudinal outcomes of these are for project personnel. This overriding question is broken down into three research questions.

Research Question 1: To what extent are the perceptions of managers' use of power and influence similar across the three stakeholder groups?

Research Question 2: To what extent does the manager's use of power and influence tactics influence project personnel's performance and their satisfaction with their managers?

Research Question 3: What are the relationships between project personnel's level of job satisfaction with the two types of managers and their overall job satisfaction, performance and level of engagement?

\section{Research methodology}

The research was conducted in the technology and project execution business unit of a large multinational company. The current capital portfolio of projects in the unit is in excess of USD20 billion, with there being approximately 2800 employees. The business unit's organizational structure is characterized by a matrix design with each area of expertise being called a "function" (e.g. civil, mechanical, electrical, process and control systems), and with functional managers providing resources for project teams. Every project team is made up of project personnel from various functions and is headed up by a project manager. The project team members report directly to their functional manager in the structure and indirectly to the project manager for the duration of the project. It is a shared-resources environment where individuals work on several projects at the same time.

This study followed a quantitative and descriptive methodology (Saunders \& Lewis, 2012). The population comprised functional managers, and project managers and project personnel in the 
project-execution cluster. The data was gathered using quota sampling to ensure that all three categories of respondents were included. Completed questionnaires were obtained from respondents in South Africa, Italy and Canada. The sample consisted of 28 project managers, 22 functional managers and 92 project personnel. Self-administered questionnaires consisting of closed-ended questions using five-point Likert scales were used. Separate questionnaires were developed for the managers and the project team personnel. The questionnaire was developed from the literature review, the original study (Dunne et al., 1978). Managers' questionnaires only included questions on the types of power and influence they used. Project team members were questioned on their perceptions of the types of power and influence used on them by both types of manager, as well as their attitudinal outcomes on the project personnel. Table 2 indicates the sources from which the questions were developed.

Table 2

Sources of influence and attitude definitions

\begin{tabular}{|l|l|}
\hline \multicolumn{1}{|c|}{ Attitude } & \multicolumn{1}{c|}{ Source } \\
\hline $\begin{array}{l}\text { Sources of influence as shown in } \\
\text { Table 1 above }\end{array}$ & $\begin{array}{l}\text { Dunne et al, 1978; French \& Raven, 1959; Benfari et al., 1986; Yukl \& Falbe, } \\
\text { 1990; Yukl et al., 2008; Gupta \& Sharma, 2008 }\end{array}$ \\
\hline Impact of manager on performance & Appelbaum et al., 2009; Kates \& Galbraith, 2007; Sy \& D'Annunzio, 2005 \\
\hline Satisfaction with manager & Robbins \& Judge, 2013 \\
\hline Overall job satisfaction & Robbins \& Judge, 2013; Wanous, Reichers \& Hudy, 1997 \\
\hline Employee engagement & Kahn, 1990; Robbins \& Judge, 2013 \\
\hline
\end{tabular}

The questionnaire was pre-tested with five individuals to test language, grammar, and general understanding, and to ensure that the online questionnaire worked as intended. A number of small readjustments were made based on this phase. Questionnaires were then distributed electronically to all respondents. Microsoft Excel and SPSS 21 were used for the data analysis. A significance level of $\alpha=0.05$ was used for all tests.

Limitations: Non-probability purposive sampling was employed in both phases of the research and the data was obtained from a single, large multinational organisation. This limits the ability to generalise the findings. Furthermore the Likert scale has certain disadvantages, such as centraltendency bias, acquiescence bias, social-desirability bias, lack of reproducibility, and the difficulty in demonstrating validity (Bertram, 2015). Whereas the first three biases are beyond the control of the researcher, the last two were addressed by having a sufficiently sized population/sample and sound theory from which the questionnaire was developed.

\section{Results and discussion}

Table 3 shows the distribution of the demographics of the sample.

Table 3

Descriptive statistics of the total sample $n=142$

\begin{tabular}{|l|c|c|}
\hline \multirow{4}{*}{ Years of experience on projects } & $<\mathbf{2}$ & $4 \%$ \\
\cline { 2 - 3 } & $\mathbf{2}$ to $\mathbf{5}$ & $22 \%$ \\
\cline { 2 - 3 } & $\mathbf{6}$ to $\mathbf{9}$ & $32 \%$ \\
\hline \multirow{3}{*}{ Management level } & $\mathbf{1 0}$ to $\mathbf{1 4}$ & $18 \%$ \\
\hline & $>\mathbf{1 5}$ & $32 \%$ \\
\hline & Junior & $26 \%$ \\
\hline & Middle & $64 \%$ \\
\cline { 2 - 3 } & Senior & $10 \%$ \\
\hline
\end{tabular}

Research Question 1: To what extent are the perceptions of managers' use of power and influence similar across the three stakeholder groups?

The project and functional managers reported on their own use of the 12 types of power and influence, whilst the project personnel reported on the use of power by both types of managers 
separately, providing four subsets of data as shown in Table 4 below. The $\mathrm{n}$ in the table indicates which part of the sample provided the data in that column. In all cases, a five-point Likert scale was used, with 1 on the scale representing "Not used at all", and 5 on the scale representing "Used frequently". To answer the question to what extent the perceptions of use of power and influence are the same across groups, a Kruskal-Wallis non-parametric test across the four independent subsets of data was conducted. The mean ranks, significance levels and ranked differences between the highest and lowest means are listed in Table 4, which is ranked by group differences. All constructs with significant statistical differences are denoted with an asterisk (*).

Table 4

Ranked differences in Kruskal-Wallis means across all groups

\begin{tabular}{|c|c|c|c|c|c|c|}
\hline \multirow{3}{*}{ Constructs } & \multicolumn{4}{|c|}{ Kruskal-Wallis mean ranks } & \multirow{3}{*}{$\begin{array}{l}\text { Asymptotic } \\
\text { significance }\end{array}$} & \multirow{3}{*}{$\begin{array}{c}\text { Ranked } \\
\text { group } \\
\text { differences } \\
\text { (max - min) }\end{array}$} \\
\hline & \multirow{2}{*}{$\begin{array}{c}\text { Project } \\
\text { managers' } \\
\text { self-report }\end{array}$} & \multirow{2}{*}{$\begin{array}{l}\text { Functional } \\
\text { managers' } \\
\text { self-report } \\
\text { n= } 22\end{array}$} & \multirow{2}{*}{$\begin{array}{c}\text { Project } \\
\text { personnel } \\
\text { views of } \\
\text { project } \\
\text { managers } \\
n=92\end{array}$} & \multirow{2}{*}{$\begin{array}{c}\text { Project } \\
\text { personnel } \\
\text { views of } \\
\text { functional } \\
\text { managers } \\
n=92\end{array}$} & & \\
\hline & & & & & & \\
\hline 1 Penalty pressure* & 73.09 & 106.77 & 109.71 & 141.38 & 0.000 & 68.29 \\
\hline 2 Empowerment* & 141.07 & 171.75 & 106.71 & 108.15 & 0.000 & 65.04 \\
\hline 3 Logical arguments* & 155.27 & 167.00 & 108.82 & 102.85 & 0.000 & 64.15 \\
\hline 4 Passion and inspiration* & 156.20 & 131.55 & 119.07 & 100.79 & 0.001 & 55.40 \\
\hline 5 Performance rating ${ }^{*}$ & 82.89 & 133.82 & 115.13 & 126.50 & 0.006 & 50.93 \\
\hline 6 Authority $^{*}$ & 78.04 & 109.02 & 123.03 & 126.01 & 0.002 & 47.97 \\
\hline 7 Shared goals* & 148.96 & 136.30 & 116.89 & 104.04 & 0.003 & 44.93 \\
\hline 8 Professionally challenging* & 133.95 & 149.25 & 111.54 & 110.86 & 0.027 & 38.39 \\
\hline 9 Good relationship* & 147.75 & 134.36 & 110.62 & 111.14 & 0.014 & 37.13 \\
\hline 10 Respect knowledge & 130.64 & 134.09 & 107.16 & 119.87 & 0.127 & 26.93 \\
\hline 11 Position \& responsibilities & 119.80 & 130.32 & 116.51 & 114.72 & 0.717 & 15.60 \\
\hline 12 Association & 115.18 & 121.23 & 119.46 & 115.36 & 0.957 & 6.05 \\
\hline
\end{tabular}

The findings show that there are significant differences in the perceived level of use for nine of the 12 power bases and influence tactics. This differs from the seminal findings of Dunne et al. (1978) in which there was a concurrence of views. The highest difference (68.29) is found with the coercive technique of penalty pressure, with both types of managers perceiving that they use this far less than their project personnel think they do. The next-highest differences are in the use of personal power in three formats: empowerment of staff (65.04), the use of logical arguments (64.15), and showing passion and inspiration (55.40). In all three cases, the managers believe they use these forms of power to a far greater extent than their staff think they do. This could be a result of attribution bias or giving normative answers (Robbins \& Judge, 2013) on the part of the managers. The fifth-largest difference is in the use of performance ratings $(50.93)-$ this is to be expected, as performance appraisals fall within the ambit of functional managers and not of project managers, as shown in the data.

These perceptual gaps could exacerbate the conflict created by the dual command structure in the matrix organisation. The differences can be summarised on the basis of two major themes: the perceived use of aspirational mechanisms of power and influence, such as passion and inspiration on the part of the manager, and the perceived use of coercive mechanisms by project personnel, predominantly the use of penalty and pressure. Gupta and Sharma (2008) called these soft and harsh power bases, respectively. This classification is applied to each power base in Table 1. This implies that, in any given situation, the prioritisation of which influence mechanism to use may not deliver the intended results, as it may be perceived to be of lower importance to the subgroup being influenced. This will have negative implications for attitudinal outcomes in the workplace and harm established psychological contracts (May, Gilson \& Harter, 2004), which will result in the impeding of personnel performance, and, in turn, will negatively impact overall company performance. 
To enable further interpretation, the top five (unshaded) and lowest three (shaded) forms of power and influence for each subset of data are shown in Table 5.

Table 5

Ranked constructs for each stakeholder group

\begin{tabular}{|l|l|l|l|l|}
\hline $\begin{array}{c}\text { Power and } \\
\text { influence } \\
\text { constructs: } \\
\text { Ranking }\end{array}$ & \multicolumn{1}{|c|}{$\begin{array}{c}\text { Project manager: } \\
\text { Self-report }\end{array}$} & $\begin{array}{c}\text { Functional manager: } \\
\text { Self-report }\end{array}$ & $\begin{array}{c}\text { Project personnel views } \\
\text { of project manager }\end{array}$ & $\begin{array}{c}\text { Project personnel } \\
\text { views of functional } \\
\text { manager }\end{array}$ \\
\hline 1 & Passion and inspiration & Empowerment & Authority & Penalty pressure \\
\hline 2 & Logical arguments & Logical arguments & Association & Performance rating \\
\hline 3 & Shared goals & Professionally challenging & Passion and inspiration & Authority \\
\hline 4 & Good relationship & Shared goals & Shared goals & Respect knowledge \\
\hline 5 & Empowerment & Good relationship & Position \& responsibilities & Association \\
\hline 10 & Performance rating & Association & Logical arguments & Shared goals \\
\hline 11 & Authority & Authority & Respect knowledge & Logical arguments \\
\hline 12 & Penalty pressure & Penalty pressure & Empowerment & Passion and inspiration \\
\hline
\end{tabular}

Comparing the findings regarding the two types of managers' self-reports: There is general concurrence between the two types of managers in believing that the top five power tactics that they use relate to the soft, personal, and relational power bases (Gupta \& Sharma, 2008; Yukl \& Falbe, 1991; Greiner \& Schein, 1988). The bottom two power bases that they believe that they use are the coercive, positional power bases of authority and penalty pressure (French \& Raven, 1959; Yukl \& Falbe, 1991; Greiner \& Schein, 1988).

Comparing the findings pertaining to the project managers' self-reports and the project personnel's views of the project manager: There is some agreement between these two views, as both stakeholders agree that shared goals, as well as passion and inspiration, are in the top four most-used power tactics. Shared goals are critically important in project work, and passion and inspiration are a highly effective form of both soft power and charismatic power (Goold \& Campbell, 2003; French \& Raven, 1959). However, there are diametrically opposed views on the empowering of staff and the power base of positional power in the form of authority, with the project managers believing that they are more empowering and less authoritarian than the project personnel believe them to be. This speaks to the problem of micromanagement and decision strangulation (Kates \& Galbraith, 2007).

Comparing the findings regarding the functional managers' self-reports and the project personnel's views of the functional manager: An important finding of this study is that the views of the functional managers and project personnel appear to be diametrically opposed, as there are no overlaps in the top five or bottom three items between the two parties. Functional managers may think that they use logical arguments and shared goals to manage their staff, but these are perceived to be the least-used forms of power according to those experiencing these tactics. The three power tactics which the functional managers believe that they use the least, namely the coercive, harsh, legitimate and positional power bases (Gupta \& Sharma, 2008; French \& Raven, 1959; Greiner $\&$ Schein, 1988), all occur in the top five most-used tactics as perceived by the project personnel.

Research Question 1 has shown that there are large, significant differences in perception between managers' perceptions of how they influence project personnel and the views of those experiencing these influence tactics, in contradiction to the findings of the foundational study by Dunne et al. (1978). These perceptual gaps have important ramifications for relationships between the three stakeholder groups, which can only negatively influence the performance of matrix organisations. Some of the outcomes of this are explored in relation to the next two research questions.

Research Question 2: To what extent does the manager's use of power and influence tactics influence project personnel's performance and their satisfaction with their managers?

The project personnel were asked in what way the two types of managers affected their performance and how satisfied they were with both types of managers. The results are shown in Table 6. 
Table 6

Managers' impact on work attitudes

\begin{tabular}{|l|c|c|c|c|c|}
\hline & \multicolumn{1}{|c|}{$\begin{array}{c}\text { Major } \\
\text { decrease }\end{array}$} & $\begin{array}{c}\text { Slight } \\
\text { decrease }\end{array}$ & No impact & $\begin{array}{c}\text { Slight } \\
\text { increase }\end{array}$ & \multicolumn{2}{|c|}{$\begin{array}{c}\text { Major } \\
\text { increase }\end{array}$} \\
\hline $\begin{array}{l}\text { Impact of project manager on project } \\
\text { personnel performance }\end{array}$ & $0 \%$ & $8 \%$ & $35 \%$ & $38 \%$ & $20 \%$ \\
\hline $\begin{array}{l}\text { Impact of functional manager on } \\
\text { project personnel performance }\end{array}$ & $2 \%$ & $12 \%$ & $32 \%$ & $34 \%$ & $21 \%$ \\
\hline \multicolumn{1}{|c|}{$\begin{array}{c}\text { Strongly } \\
\text { disagree }\end{array}$} & Disagree & $\begin{array}{c}\text { Neither agree } \\
\text { nor disagree }\end{array}$ & Agree & $\begin{array}{c}\text { Strongly } \\
\text { agree }\end{array}$ \\
\hline Satisfaction with project manager & $3 \%$ & $12 \%$ & $22 \%$ & $52 \%$ & $11 \%$ \\
\hline Satisfaction with functional manager & $5 \%$ & $15 \%$ & $23 \%$ & $41 \%$ & $15 \%$ \\
\hline
\end{tabular}

Although, for individual respondents, there were significant differences between their attitudes to the two types of managers, the data shows that, overall, the functional and project managers had the same effect on project personnel performance and that the levels of satisfaction with them were similar. However, there is a widespread divergence of opinions as to the influence of both types of managers. The data highlights that there is a dual role to be played by the two types of managers in a matrix organisation in driving performance: essentially, both the direct and indirect relationships are important in driving staff and, therefore, organisational performance.

To answer the question whether relationships exist between project personnel's satisfaction with their managers and their influence on performance, on the one hand, and the methods the managers use to influence them, on the other, Spearman coefficient tests were conducted. These measured the strength and significance of the relationship between the 12 constructs of power and influence used by the managers with respect to project personnel satisfaction with their manager and the perceived impact of managers on project personnel performance. The results are presented in Table 7, with all significant relationships being denoted with an asterisk (*). The average correlation for each attitudinal outcome is also presented.

Table 7

Correlations between type of power and influence used and performance and satisfaction with manager

\begin{tabular}{|l|c|c|c|c|}
\hline \multicolumn{1}{|c|}{ Power and influence } & $\begin{array}{c}\text { Satisfaction with } \\
\text { project manager }\end{array}$ & $\begin{array}{c}\text { Project manager } \\
\text { impact on } \\
\text { performance }\end{array}$ & $\begin{array}{c}\text { Satisfaction with } \\
\text { functional } \\
\text { manager }\end{array}$ & $\begin{array}{c}\text { Functional } \\
\text { manager impact } \\
\text { on performance }\end{array}$ \\
\hline Association & $0.601^{*}$ & $0.572^{*}$ & $0.643^{*}$ & $0.559^{*}$ \\
\hline Authority & $0.275^{*}$ & $0.467^{*}$ & $0.443^{*}$ & $0.372^{*}$ \\
\hline Empowerment & $0.704^{*}$ & $0.557^{*}$ & $0.678^{*}$ & $0.503^{*}$ \\
\hline Good relationship & $0.681^{*}$ & $0.480^{*}$ & $0.645^{*}$ & $0.504^{*}$ \\
\hline Logical arguments & $0.631^{*}$ & $0.614^{*}$ & $0.685^{*}$ & $0.571^{*}$ \\
\hline Passion and inspiration & $0.702^{*}$ & $0.609^{*}$ & $0.674^{*}$ & $0.609^{*}$ \\
\hline Penalty pressure & 0.166 & $0.251^{*}$ & -0.072 & -0.060 \\
\hline Performance rating & $0.403^{*}$ & $0.365^{*}$ & $0.295^{*}$ & 0.171 \\
\hline Position responsibilities & $0.591^{*}$ & $0.486^{*}$ & $0.576^{*}$ & $0.444^{*}$ \\
\hline Professionally challenging & $0.484^{*}$ & $0.366^{*}$ & $0.556^{*}$ & $0.482^{*}$ \\
\hline Respect knowledge & $0.701^{*}$ & $0.682^{*}$ & $0.664^{*}$ & $0.531^{*}$ \\
\hline Shared goals & $0.728^{*}$ & $0.566^{*}$ & $0.651^{*}$ & $0.540^{*}$ \\
\hline Average correlations over all & & & & $0.537^{*}$ \\
\hline power and influence tactics & $0.556^{*}$ & $0.501^{*}$ & $0.435^{*}$ \\
\hline
\end{tabular}

For the 48 correlations, all showed significant relationships except for four related to the use of penalty pressure and performance rating. This is in accordance with the findings of Koslowsky et al. (2001). This shows the strong effect of the types of influence and power used by the managers, on the performance of project personnel and their satisfaction with their managers. The average correlations show a 25 per cent covariance between type of influence tactic used and the two attitudinal outcomes. 
Table 7 highlights that the use of penalty pressure had the lowest correlations in all four cases, with performance ratings being in the lowest three in all four cases.

For ease of interpretation, the three highest correlations between power and influence tactic used and the two attitudinal variables are shown in ranked order in Table 8.

Table 8

Project personnel perceptions: Highest three correlations

\begin{tabular}{|l|l|l|l|l|}
\hline $\begin{array}{c}\text { Power and } \\
\text { influence tactic }\end{array}$ & \multicolumn{1}{|c|}{$\begin{array}{c}\text { Satisfaction with } \\
\text { project manager }\end{array}$} & $\begin{array}{c}\text { Project manager impact } \\
\text { on performance }\end{array}$ & $\begin{array}{c}\text { Satisfaction with } \\
\text { functional manager }\end{array}$ & $\begin{array}{c}\text { Functional manager } \\
\text { impact on } \\
\text { performance }\end{array}$ \\
\hline $1^{\text {st }}$ & Shared goals & Respect knowledge & Logical arguments & Passion and inspiration \\
\hline $2^{\text {nd }}$ & Empowerment & Logical arguments & Empowerment & Logical arguments \\
\hline $3^{\text {rd }}$ & Passion and inspiration & Passion and inspiration & Passion and inspiration & Association \\
\hline
\end{tabular}

An important theme emerges in Table 8. The use of passion and inspiration, logical arguments, and empowering staff are the power tactics most highly associated with both performance of project staff and satisfaction with their managers. These are all related to the soft bases as described by Gupta and Sharma (2008), as well as personal power (French \& Raven, 1959; Greiner \& Schein, 1988). Gupta and Sharma (2008) found that there is more compliance with soft bases of power and that a positive work culture should be cultivated to enhance satisfaction with the manager. The findings also confirm the finding by Yukl and Falbe (1991) that personal power is more important than positional power as a source of influence on the performance of subordinates.

It is interesting that the establishment of shared goals and the empowering of staff are highly correlated with satisfaction with the project manager (Sy \& Côté, 2004). This highlights the transactional, short-term nature of the psychological contract with the project manager (Rousseau, 2004). The expert power bases (French \& Raven, 1959) of respect for the knowledge of project managers and their use of logical arguments, with both leading to confidence in the advice given, yielded the highest correlation with performance. This speaks to the use of expert power in trusting the project manager in the role of integration and coordination, thus creating a flow of information and the alignment of teams goals and objectives (Kates \& Galbraith, 2007; Sy \& D'Annunzio, 2005).

The highest drivers of personnel performance by the functional manager are found to be the use of passion and inspiration, logical arguments, and, then, association. This demonstrates the relational, ongoing nature of the psychological contract with the line manager (Rousseau, 2004) and the importance of the use of soft power bases (Gupta \& Sharma, 2008). This also confirms the advice that managers need to build and maintain strong relationships (Assudani \& Kloppenborg, 2010).

A major finding of this study is the low correlations shown by the use of power and influence tactics, which reflect the hard power sources, and by the use of coercive power, positional power and power distance (French \& Raven 1959; Gupta \& Sharma, 2008). Penalty pressure, performance rating, and the use of authority were consistently rated the lowest in influencing the performance of project staff, as well as their satisfaction with the managers. This shows that, in a professional work environment, it may well be counter-intuitive to root motivation in a coercive or positional power base, and that personal power should be used (Yukl \& Falbe, 1991).

Two prominent themes emerge with regard to this research question. Firstly, that positive influence mechanisms such as the use of passion and inspiration, logical arguments, shared goals, and empowerment are more effective than punitive influence mechanisms in driving performance of project personnel and satisfaction with their managers. The implication for the organisation is that it is crucial for managers to embrace the positive influence mechanisms, whilst reserving the coercive techniques for managing individual cases of poor performance. The use of personal power in lieu of positional power will achieve more meaningful results. Secondly, it shows that there are different psychological contracts between the two types of managers and their project staff. 


\section{Research Question 3: What are the relationships between project personnel's level of job satisfaction with the two types of managers and their overall job satisfaction, performance and level of engagement?}

Project personnel were asked the question: "Overall, am I satisfied with my current job situation?", a widely used summative psychology scale (Wanous et al., 1997). To develop an understanding of employee engagement, the three main dimensions proposed by Kahn (1990) were used. These related to, firstly, finding meaning in job roles, tasks and work interactions; secondly, feeling safe to express oneself without fear of consequences for self-image or career prospects; and, thirdly, the use of physical, emotional and intellectual energy to perform one's job. A composite score from these three questions was then used. All of these scales were five-point Likert scales. The resulting correlations between this data and the data in Table 6 are shown below in Table 9, with significant relationships indicated with an asterisk $(*)$.

Table 9

Correlations between satisfaction with manager and overall job satisfaction, employee engagement and manager's impact on performance

\begin{tabular}{|l|c|c|}
\hline \multicolumn{1}{|c|}{$\begin{array}{c}\text { Attitudinal variables: } \\
\text { Spearman's rho }(\boldsymbol{\rho})\end{array}$} & $\begin{array}{c}\text { Satisfaction with supervision by } \\
\text { project manager }\end{array}$ & $\begin{array}{c}\text { Satisfaction with supervision by } \\
\text { functional manager }\end{array}$ \\
\hline Overall job satisfaction & 0.178 & $0.452^{*}$ \\
\hline Employee engagement & $0.238^{*}$ & $0.393^{*}$ \\
\hline Impact of manager type on performance & $0.590^{*}$ & $0.610^{*}$ \\
\hline
\end{tabular}

For all three variables, satisfaction with the functional manager has stronger relationships compared with the project manager. This illustrates a new key finding within the duality of command. A significantly strong correlation between overall job satisfaction and satisfaction with the manager only exists for the functional manager. This is an important finding. There is no relationship between satisfaction with the project manager and overall job satisfaction. This suggests that project personnel first have an allegiance to their role in their functional area rather than to the project team. This finding can be explained by virtue of the fact that it is more likely that project personnel have a relational psychological contract with the functional manager and a transactional psychological contract with the project manager (Rousseau, 2004) due to typically short-term project life cycles combined with being shared resources working on multiple projects simultaneously. Relational psychological contracts are not time-bound and are nurtured through mentoring and socialisation. This responsibility usually lies with the functional manager (Millward \& Hopkins, 1998). The findings highlight the important role that the functional manager plays in the work life of project personnel. These finding also offer some solutions to the high-level challenges indicated by Packendorff and Lindgren (2014) as to the consequences of projectification of the workplace.

Satisfaction with both types of managers is significantly positively correlated with employee engagement. Again, there is a far stronger correlation with regard to the functional manager. Employee engagement is critical to the performance of the company, as research has shown a correlation between employee engagement and meaningful business outcomes (Harter et al., 2002). The higher correlation of the functional manager with employee engagement compared with the project manager shows that a functional manager in a solid line relationship is much better equipped to satisfy the needs, and manage the expectations, of project personnel (Assudani \& Kloppenborg, 2010; Garvare \& Johansson, 2010). This finding is supported by May et al. (2004:30), who showed the "positive effects of supportive managerial behaviour on creativity, task performance and psychological safety". However, the project manager also has a significant effect on employee engagement.

The strongest correlations exist between satisfaction with both managers and levels of personnel performance, with approximately 36 per cent of the manager's influence on performance being explained by employee satisfaction with their managers. This indicates that both managers have an equal responsibility to put measures in place to ensure that project 
personnel are satisfied with their supervision and that there are performance-management systems to drive performance on projects (Sy \& D'Annunzio, 2005). Harter et al. (2002), in their metaanalysis of employee engagement and job satisfaction, highlight the importance of the influence of the supervisor on both employee engagement and satisfaction with the company, and found that the construct most highly related to performance was satisfaction with the supervisor. Their findings are supported by the present study.

\section{Conclusion}

The study shows that both functional and project managers have a crucial role to play in employee performance, but that a challenge is the large perceptual gap between managers and project personnel of how this management is actually taking place and being viewed. This perceptual gap may exacerbate the conflict created by a dual chain of command. Managers and employees tend to have diametrically opposed views, highlighted by the inverse ranking of the use of many aspects of personal and positional power tactics. Both parties need to understand this large difference in perceptions, as well as its ramifications.

A noteworthy finding is that the functional manager has stronger relationships than the project manager for all attitudinal outcomes. In particular, there is a strong relationship between the functional manager only and overall job satisfaction, highlighting the vital role of the direct line management relationship. The data shows that the two types of managers do, and should, use different types of power and influence and should be aware of the different psychological contracts between them and project personnel. The most crucial observation for managers is that the use of personal power instead of positional power will achieve more meaningful results. By using the findings of this study to understand perceptions of power usage and its impact on the outcomes of performance, employee engagement and overall satisfaction, managers could deliberately harness their personal-influence skills and power bases to focus on achieving optimal project outcomes and thus improving organisational performance.

A further broad observation that can be made is that, despite the observed perceptual gap, project personnel still show a strong correlation between their satisfaction with both managers (albeit less for the project manager) and their own performance. This gives rise to the question whether this correlation exists because of the management style, or despite the management style. This notion ties in with the idea that, even though project personnel are often overloaded, "improvisational measures and fire-fighting" result in most projects being "delivered satisfactorily" (Packendorff \& Lindgren, 2014). In their broad-view analysis of projectification, Packendorff and Lindgren (2014) associate this relative success with heroic action. The question that remains is whether this heroic action is on the management side, or on the side of project personnel. Pink (2010) claims that the motivation of personnel to do well is not dependent on the carrot-and-stick method anymore, but on the intrinsic motivation to do a task that makes sense to them personally.

\section{$7 \quad$ Recommendations for future research}

This study was conducted in a single, large multinational organisation. Future research should, therefore, validate the above findings by conducting similar studies in other industries. It would be interesting to conduct a comparative study of semi-skilled workers' and knowledge workers' responses to different power bases. Another study could consider how project personnel respond when receiving conflicting advice or orders from their functional and project managers. Future research is also proposed to determine whether project personnel's motivation to perform well and achieve job satisfaction is the result of the predominantly carrot-and-stick method employed by managers, the 'heroic action' of managers, or whether it is more intrinsically driven. 


\section{References}

APPELBAUM, H.S., NADEAU, D. \& CYR, M. 2009. Performance evaluation in a matrix organization: A case study (Part 3). Industrial and Commercial Training, 41(1):9-14. Available at: Doi: 10.1108/00197850910927705.

ASSUDANI, R. \& KLOPPENBORG, T.J. 2010. Managing stakeholders for project management success: An emergent model of stakeholders. Journal of General Management, 35(3):67-80.

BARTLETT, C.A. \& GHOSHAL, S. 1990. Matrix management: Not a structure, a frame of mind. Harvard Business Review, 68(4):138-145.

BENFARI, R.C., WILKINSON, H.E. \& ORTH, C.D. 1986. The effective use of power. Business Horizons, 29(3):12-16. Available at: Doi: 10.1016/0007-6813(86)90002-9.

BERTRAM, D. 2015. Likert scales. Available at: http://my.ilstu.edu/ eostewa/497/Likert\%20topic-danelikert.pdf [accessed October 2015].

BRASS, D.J. \& BURKHARDT, M.E. 1993. Potential power and power use: An investigation of structure and behavior. The Academy of Management Journal, 36(3):441-470.

DAVIS, S.M. \& LAWRENCE, P.R. 1978. Problems of matrix organizations. Harvard Business Review, 56(3):131-142.

DUNNE, E.J., STAHL, M.J. \& MELHART, L.J. 1978. Influence source of project and functional managers in matrix organizations. Academy of Management Journal, 21(1):135-140.

FRENCH, J.R. \& RAVEN, B. 1959. The bases of social power. Studies in Social Power, 150:150-167.

GALBRAITH, J.R. 1971. Matrix organization designs: How to combine functional and project forms. Business Horizons, 14(1):29-40. Doi: 10.1016/0007-6813(71)90037-1.

GARVARE, R. \& JOHANSSON, P. 2010. Management for sustainability - a stakeholder theory. Total Quality Management \& Business Excellence, 21(7):737-744. Available at: Doi: 10.1080/14783363.2010.483095.

GOOLD, M. \& CAMPBELL, A. 2003. Making matrix structures work: Creating clarity on unit roles and responsibility. European Management Journal, 21(3):351-363. Available at: Doi: 10.1016/S02632373(03)00048-3.

GREINER, L.E. \& SCHEIN, V.E. 1988. Power and organization development; mobilizing power to implement change. United States of America: Addison-Wesley Publishing Company.

GUPTA, B. \& SHARMA, N.K. 2008. Compliance with bases of power and subordinates' perception of superiors: Moderating effect of quality of interaction. Singapore Management Review, 30(1):1-24.

HARTER, J.K., SCHMIDT, F.L. \& HAYES, T.L. 2002. Business-unit-level relationship between employee satisfaction, employee engagement, and business outcomes: A meta-analysis. Journal of Applied Psychology, 87(2):268-279.

JOYCE, W.F. 1986. Matrix organization: A social experiment. The Academy of Management Journal, 29(3):536-561.

KAHN, W.A. 1990. Psychological conditions of personal engagement and disengagement at work. The Academy of Management Journal, 33(4):692-724.

KATES, A. \& GALBRAITH, J.R. 2007. Designing your organization: Using the star model to solve 5 critical design challenges. Jossey-Bass, 5.

KIPNIS, D., SCHMIDT, S.M. \& WILKINSON, I. 1980. Intraorganizational influence tactics: Explorations in getting one's way. Journal of Applied Psychology, 65(4):440-452.

KOSLOWSKY, M., SCHWARZWALD, J. \& ASHURE, S. 2001. On the relationship between subordinates' compliance to power sources and organisational attitudes. Applied Psychology: An International Review, 50(3):455-476.

LARSON, E.W. \& GOBELI, D.H. 1987. Matrix management: Contradictions and insights. California Management Review, 29(4):126-138.

MAY, D.R., GILSON, R.L. \& HARTER, L.M. 2004. The psychological conditions of meaningfulness, safety and availability and the engagement of the human spirit at work. Journal of Occupational and Organizational Psychology, 77(1):11-37. 
MILLWARD, L.J. \& HOPKINS, L.J. 1998. Psychological contracts, organizational and job commitment. Journal of Applied Social Psychology, 28(16):1530-1556. Available at: Doi: 10.1111/j.15591816.1998.tb01689.x.

MITCHELL, R.K., AGLE, B.R. \& WOOD, D.J. 1997. Toward a theory of stakeholder identification and salience: Defining the principle of who and what really counts. The Academy of Management Review, 22(4):853-886.

NICHOLAS, J.M. \& STEYN, H. 2008. Project management for business, engineering and technology. ( $3^{\text {rd }}$ ed.) Burlington, Massachusetts: Butterworth-Heinemann.

PACKENDORFF, J. \& LINDGREN, M. 2014. Projectification and its consequences: Narrow and broad conceptualisations. South African Journal of Economic and Management Sciences, 17(1).

PINK, D.H. 2010. Drive: The surprising truth about what motivates us. (Kindle ed.) Canongate Books. RAVEN, B.H. 2008. The bases of power and the power/interaction model of interpersonal influence. Analyses of Social Issues \& Public Policy, 8(1):1-22.

REESER, C. 1969. Some potential human problems of the project form of organization. The Academy of Management Journal, 12(4):459-467.

RIZZO, J.R., HOUSE, R.J. \& LIRTZMAN, S.I. 1970. Role conflict and ambiguity in complex organizations. Administrative Science Quarterly, 15(2):150-163.

ROBBINS, S.P. \& JUDGE, T.A. 2013. Organisational behaviour: Pearson Education. Boston

ROUSSEAU, D.M. 2004. Psychological contracts in the workplace: Understanding the ties that motivate. Academy of Management Executive, 18(1):120-127.

SAUNDERS, M. \& LEWIS, P. 2012. Doing research in business \& management. Edinburgh Gate: Pearson.

SY, T. \& CÔTÉ, S. 2004. Emotional intelligence: A key ability to succeed in the matrix organization. Journal of Management Development, 23(5):437-455. Available at: Doi: 10.1108/02621710410537056.

SY, T. \& D'ANNUNZIO, L.S. 2005. Challenges and strategies of matrix organizations: Top-level and midlevel managers' perspectives. Human Resource Planning, 28(1):39-48.

THAMHAIN, H.J. \& GEMMILL, G.R. 1974. Influence styles of project managers: Some project performance correlates. Academy of Management Journal, 17(2):216-224.

WANOUS, J.P., REICHERS, A.E. \& HUDY, M.J. 1997. Overall job satisfaction: How good are single-item measures? Journal of Applied Psychology, 82(2):247-252.

WILLER, D., LOVAGLIA, M.J. \& MARKOVSKY, B. 1997. Power and influence: A theoretical bridge. Social Forces, 76(2):571-603. Available at: Doi: 10.1093/sf/76.2.571.

WOCKE, A \& SUTHERLAND, M. 2008. The impact of employment equity regulations on psychological contracts in South Africa. International Journal of Human Resource Management, 19(4):528-542.

YUKL, G. \& FALBE, C.M. 1990. Influence tactics and objectives in upward, downward, and lateral influence attempts. Journal of Applied Psychology, 75(2):132-140.

YUKL, G. \& FALBE, C.M. 1991. Importance of different power sources in downward and lateral relations. Journal of Applied Psychology, 76(3):416-423.

YUKL, G., KIM, H. \& FALBE, C.M. 1996. Antecedents of influence outcomes. Journal of Applied Psychology, 81(3):309-317.

YUKL, G., SEIFERT, C.F. \& CHAVEZ, C. 2008. Validation of the extended influence behavior questionnaire. The Leadership Quarterly, 19(5):609-621. Available at: Doi: 10.1016/j.leaqua.2008.07.006. 